\title{
Impact of Foreign Direct Investment on Volatility of Stock Market (An Evidence From Pakistani Market)
}

\author{
Irfan Ali \\ Mba-Final Foundation University Islamabad
}

\begin{abstract}
Investment markets are an important source of developing the economy of a country. Stock market is the fundamental part of capital market and it is associated with the investments, savings and economic growth of the country. Some growing countries are emerging with their tactics of bringing changes in their economies by considering the capital flows because of the global market as this market provides a vast opportunity to all the countries for their economic flourishment. This change affects the Stock market and stock market is one of the major part of the developed markets throughout the globe.

Karachi Stock Exchange (KSE) is one of the major role player in a Pakistan's economy. And because of its high index FDI investors are getting opportunities to boom themselves and our country is also growing because of their roles.

Primary cause of this study is to find out the impact of Foreign Direct Investment on the stock market and also to examine the other factors in development of stock markets.

Summary: $\quad$ Foreign Direct Investment is best known for its capital development for a country they are investing. Pakistan is one of those countries experiencing Foreign Direct Investment to take a part in increasing capital structure. Stock market index of Pakistan is at peak because of both; local and foreign Investors showing interest in variety of businesses.

Mainly, Foreign Direct Investments (FDIs) are becoming important resource for improving the economy of a country.

This research includes broader concept of understanding relationships between Foreign Direct Investments (FDIs) and the stock Markets. Moreover, this research highlights the actual interest played by Stock Market and FDI and the other determinants affecting the both variables.

Different tools and techniques have been used to find out the effect of FDI on the Stock Market. Numbers of tests have been used to determine the effect between the both.
\end{abstract}

\section{Introduction}

Foreign Direct Investments (FDIs) is an investment that is done to expand operations in a country either by the local or a foreign company.

A foreign direct investment includes Mergers and Acquisition, Generating new profits, investing profits etc. There are three types of FDI'S:-

1. Horizontal.

2. Vertical.

3. Platform.

Foreign Direct Investment is considered to be a primary source of expanding the country's economy. Similarly, stock markets boost the economic growth by providing number of investment opportunities. Stock Market is a fundamental part of a financial system of a country's economy. The key hold of financing relates a profitable growth for the economy because a solid monetary system will result in a strong economic growth and stability. Stock Market helps to increase financial progress of the country and its role cannot be denied. Foreign Direct Investment is a greater source of capital flows that allows most of the developed countries to expand technology, managerial skills, capital formation, core-competencies and competitive environment.

There is a strong relationship between the FDI and Stock Market. It can be simply understood by comparing their roles as:

- Foreign Direct Investment increases the economic development of a country.

- Foreign Direct Investment supports the stock market development.

- Stock Market has a positive effect on economy.

- Stock Market increases the opportunities of Investments. 


\section{Literature Review}

Different contributions made by different researchers have showed their interest in this field.

Singh (1997) found positive relationship between stock market development and the economic growth.

Garcia and Liu (1999) used macroeconomic elements of stock market development on industrialized and developing countries data particularly stock market capitalization.

Hidalgo (2000) admitted a strong relationship of exchange rate variables with the Foreign Direct Investment.

Krkoska (2001) explained relationship between Foreign Direct Investment and the capital formation and obtained results using different countries data.

Daniela (2002-03) found the Stock market determinants around the world and found the effects on local exchanges.

Mihir and Fritz (2005) used Regression to explain relationship between FDI and the Capital formation.

Naceur (2007) studied macroeconomic factors that influence stock market in the North African area. In his research he found that financial intermediary, stock market liquidity, saving rate are important elements of stock market development.

Shabaz (2008) studied the relationship between stock market development and economic growth in Pakistan.

Yartey (2008) in his research studied many factors necessary for foreign Investment. Important factors were; fair trading practices, listing requirements, regulatory reform etc.

Robert (2008) in his research studied the relationship between stock market development and the exchange rate fluctuations. In his observation he didn't find any close connection between the two.

Researchers Anokye and Adam (2009) studied the impact of Foreign Direct Investment on stock market in Ghana by using co-integration and Accounting Methods.

Raemon (2009) in his research studied the influence of foreign capital inflows on stock market development.

\section{Foreign Direct Investment And The Stock Market}

Stock Market is a rapid progressing market in our country and Karachi Stock Exchange (KSE) is known for its high index. The most recent, KSE - 100 index closed at 26,490 points by gaining 442 points, while KSE - 30 index closed at 19,500 points by gaining 143 points. There are many other factors that influence the trade in the stock market. Some determinants/factors are business earnings, mergers and acquisition, exchange rate, interest rate, GDP, GNP etc.

Karachi Stock Exchange (KSE) plays a major role in developing the economy of a country. In Pakistan Karachi Stock Exchange (KSE) is a huge exchange.

Summary of Karachi Stock Exchange

\begin{tabular}{|c|c|c|c|c|}
\hline & 2008 & 2007 & 2006 & 2005 \\
\hline Corporations & 652 & 658 & 658 & 659 \\
\hline New Corporations & 5 & 12 & 14 & 15 \\
\hline Fund (Rs.bil) & 49.24 & 49.72 & 41.45 & 54.10 \\
\hline Capital (Rs.bil) & & & & \\
\hline $\begin{array}{l}\text { Shares Turnover } \\
\text { (Rs.bil) }\end{array}$ & $\begin{array}{l}690.15 \\
56.90\end{array}$ & $\begin{array}{l}631.12 \\
68.82\end{array}$ & $\begin{array}{l}496.16 \\
104.74\end{array}$ & $\begin{array}{l}438.52 \\
88.38\end{array}$ \\
\hline $\begin{array}{l}\text { Avg. Shares } \\
\text { Turnover (mil) } \\
\text { Avg. Market } \\
\text { Capitalization } \\
\text { (Rs.bil) }\end{array}$ & 4622.98 & 4019.43 & 2801.25 & 351.93 \\
\hline
\end{tabular}

Several sectors played an important role in boosting the stock market .Few major sectors that participated were Chemicals and Pharmaceuticals, Cement etc.

Foreign Direct Investment in Pakistan includes two modules i.e. Port Folio Investment and the Foreign Direct Investment. Foreign Direct Investment is the basis for growing capital structure of Pakistan. Countries contributing for foreign private investment in Pakistan are namely United Arab Emirates, U.S.A, and China. 


\begin{tabular}{|l|l|l|l|l|l|}
\hline \multicolumn{3}{|c|}{ Contribution made by various sectors on Karachi Stock Exchange } \\
\hline Sectors & $\begin{array}{l}\text { Overall Index } \\
\text { Percentage }\end{array}$ & $\begin{array}{l}\text { MC } \\
\text { Percentage }\end{array}$ & $\begin{array}{l}\text { ACM } \\
\text { (Rs.Bil) }\end{array}$ \\
& & & & \\
& & & & \\
& 2006 & 2007 & 2007 & 2008 \\
\hline Chemicals and Pharmaceuticals & 19 & 23.5 & 242 & 370 \\
Cement & 11 & 24.5 & 130 & 157 \\
Fuel and Energy & 9.2 & 1.5 & 1098 & 1267.5 \\
Transport and Communication & 44 & 36 & 245 & 242 \\
Banks and Financial Institutions & 41 & 117 & 1342 & 1965 \\
& & & & \\
& & & & & \\
& & & & & \\
\end{tabular}

\section{Model And Data Collection}

In order to find out the favorable results for this research linear modeling is used. An equation has been made to observe the effect of both variables.

\section{MC $=$ FDI+GNP+INF \\ VARIABLES : \\ MARKET CAPITILIZATION \\ * FDI \\ * GNP \\ * INFLATION}

\section{Methodology}

In this research paper the measurement of stock market is done through market capitalization functioning FDI, GNP.INF. Co-integration test is used to establish a connection between the FDI and factors/variables and this is an advanced approach for testing economic variables. An equation has been derived for these variables following the time series vector $(\mathrm{X}$ and $\mathrm{Y})$

$\mathrm{X}=\mathrm{Y} \quad$ - …......eq:1

$\mathrm{Y}=\mathrm{MC} \quad \quad \ldots \ldots \ldots$.eq:2

Rearranging the equation $1 \& 2$

$\mathrm{X}=\mathrm{FDI}+\mathrm{GNP}+\mathrm{INF} \ldots \ldots . . \mathrm{eq}: 3$

Using time series $\mathrm{Z}$ is equal to $\mathrm{X}+\mathrm{Z}$

$\mathrm{Z}=\mathrm{FDI}+\mathrm{GNP}+\mathrm{INF} / \mathrm{X}$

$\mathrm{u}$ is a constant, delta $=\mathrm{FDI}+\mathrm{GNP}+\mathrm{INF}$

So,

$\mathrm{Z}=\mathrm{Y} / \mathrm{X} \times \mathrm{u} \times$ delta

Descriptive statistics is also used:

Mean, Median, Maximum, Minimum, Standard Deviation, Kurtosis, Skewness

Positive result is shown for FDI w.r.t the variables. It is easily understood that FDI and Stock Market Development is necessary for the growth of economy, stock market development and GNP are positively showing an effect on stock market development.

VI. Results

Correlation and the Descriptive Statistics

\begin{tabular}{|l|l|l|l|l|}
\hline Variables & FDI & GNP & INF & MC \\
\hline Mean & -0.9960 & 8.6453 & 1.9435 & 27.6485 \\
\hline Median & -0.8743 & 10.4535 & 3.5643 & 22.4345 \\
\hline Std. Dev. & 2.3413 & 0.3322 & 0.6285 & 2.1423 \\
\hline Minimum & -5.2784 & 9.6434 & 1.7432 & 24.4452 \\
\hline
\end{tabular}




\begin{tabular}{|l|l|l|l|l|}
\hline Maximum & 0.3465 & 10.2399 & 4.2343 & 27.4652 \\
\hline Kurtosis & 5.2378 & 2.3343 & 1.3245 & 2.4225 \\
\hline Skewness & -0.9759 & -0.1260 & 0.3435 & 0.23445 \\
\hline FDI & 0.9754 & 0.4512 & 0.4757 & 0.9324 \\
\hline INF & -0.2120 & -0.9867 & 1.0034 & -0.3424 \\
\hline GNPC & 0.4754 & 1.0215 & 0.5432 & 0.8845 \\
\hline MC & 1.4353 & 0.4564 & 0.2421 & 1.0565 \\
\hline
\end{tabular}

\section{Sensitivity Analysis}

\begin{tabular}{|l|l|l|l|}
\hline \multicolumn{4}{|c|}{ Dependent Variable: Market Capitilization } \\
\hline Variable & T-Stat & $\begin{array}{l}\text { Co- } \\
\text { efficient }\end{array}$ & Probability \\
\hline GNPC & 2.543 & 3.024 & 0.0013 \\
\hline INF & -0.342 & -0.103 & 0.0254 \\
\hline FDI & 2.545 & 0.199 & 0.0937 \\
\hline
\end{tabular}

Diagnostic tests have been made using co-relation, regression. The results used showed that regression is definite showing positive result.

\section{Conclusion}

In this research paper multiple variables were studied to find out the relationship between FDI and the Stock Market. Past researched data and historical data is used. Model was used for regression analysis. This model included various variables affecting the FDI and stock Market. These variables were market capitalization, FDI, GNP and inflation rate. Time series analysis was used because the data was in years. Results shown were positive thus influencing the impact of Foreign Direct Investment and the Stock Market. GNP also showed a positive result and implied that economic growth is necessary for the stock market development.

\section{Recommendations}

Effect of observed results is very much complex. So government of Pakistan should follow certain steps to build its stand for the growth of economy and to boost Foreign Direct Investment:-

* Establishment of the Infra-structure.

* Interest rates should be lowered through fiscal policy.

* Foreign Exchange rates should also be lowered.

* Political Stability.

If these recommendations are selected as objectives then the development of stock market can reach to its peak.

\section{References}

[1] Dickey, Fuller (1979) "Distribution of the estimates for autoregressive time series with unit root", Journal of the American Statistical Association.

[2] Johansen, S. (1988) Statistical Analysis of Co-integrating Vectors. Journal of Economic Dynamics and Control 12, $231-54$.

[3] Hines, J. R. Jr., and Er. M. Rice (1994) Fiscal Paradise: Foreign Tax Havens and American Business. The Quarterly Journal of Economics 109:1, 149-82.

[4] Hines, J. R. Jr. (1996) Altered States: Taxes and the Location of Foreign Direct Investment in America.

[5] Gastanaga, V. M., J. B. Nugent, and B. Pashamova (1998) Host Country Reforms and FDI Inflows: How Much Difference Do They Make?

[6] Garcia, V.F. and Liu, L. (1999), Microeconomic Determinants of Stock Market Development, Journal of Applied Economics

[7] Khan, Ashfaque H., and Yun-Hwan Kim (1999) EDRC (Report Series No. 66.) 